\title{
The Content Analysis, the Presentation, and the Instrument Readability of Indonesian Proficiency Test
}

\author{
Laili Etika Rahmawati ${ }^{1}$, Sarwiji Suwandi ${ }^{2}$ \\ Kundharu Saddhono ${ }^{3}$ \& Budhi Setiawan ${ }^{4}$ \\ ${ }^{1}$ The lecturer of Indonesian Language Education Program, \\ Teacher Training and Education Faculty of Universitas Muhammadiyah Surakarta, \\ Teacher Training and Education Faculty of Universitas Muhammadiyah Surakarta, \\ The student of Doctorate Program of Indonesian Language Education of Sebelas Maret \\ University of Surakarta \\ email: Laili.Rahmawati@ums.ac.id
}

\begin{abstract}
The research has aim to describe the result of the content analysis, the presentation, and the instrument readability of the Indonesian proficiency test. The method used in the research was the qualitative descriptive research method. The objects that were examined in the research were the instruments of Indonesian proficiency test which consists of five parts, namely listening, responding the rules, reading, speaking, and writing. The analysis technique used was the content analysis with the data validity test using the triangulation theory. Based on the result analysis towards the content, the presentation, and the instrument readability of the Indonesian proficiency test, it could be concluded that the instrument of Indonesian proficiency test was still containing some weaknesses. It was related to the content aspect which had analyzed based on the tested skill and the materials. The skill of responding the rules in the Indonesian proficiency test has not relevant yet with the assessment theory of pragmatic and communicative. The materials tested in the Indonesian proficiency test allows the differences of ability based on the background of test participants. The multiple choice test form in Indonesian proficiency test consider as the weaknesses of the instrument.
\end{abstract}

Keywords content, presentation, readability, Indonesian proficiency test

\section{INTRODUCTION}

The language competence consists of four language skills, i.e. listening, speaking, reading, and writing. The language competence is an action in using the language based on reality for the communication purpose. The language activities or work staged language competence is a real manifestation of one's linguistic competence. The level of linguistic competence of someone is generally reflected in his/her language skills.

Various aspects of language and communicative functions of comprehension and the language use, should be integrated in the language competency test. That is, through the linguistic tests will measure a person's knowledge of the language, but it must be integrated in the form of understanding and use of language naturally and contextual. The linguistic tests which has intended to measure the grammatical competence as a basic ability to communicate is necessary to get the special attention. However, the linguistic test should not be separated from the communicative function of language, and if enforced, it would turn into another kind of language tests that do not measure the language competence. Thus, the language competence test will be tangible as the test of language, the understanding and the use of language. Concretely, the language competence test that will involve the four aspects must be in the 
contextual side. That is, it must be in a situation of actual use, reasonable, and laid in a particular context. If the aspects above being ignored, the test of that four language skills could be plunged into an isolated and artificial test. Such test tendency actually is consider as the main problem of the language testing nowadays (Brown, 2004:10).

Meanwhile, the traditional language testing is still being used in the measurement of the language competence. The traditional language testing here is intended as a language testing that only has characteristics which require the activity of a test participant to choose an answer, show the knowledge mastery, and recall or recognition. Therefore, the low or the high score of the participant is not necessarily reflects his/her level of competence.

Various forms of test which has provided the answer options, for example, the form of an objective test questions like the true-false type and the multiple-choice type, are the examples of a traditional test. Various tests type that measure the competence of language such as test of structures and vocabulary which were belonging to discrete type, clearly categorized as a matter of traditional tests. In fact, the questions that measure language competence such as listening and reading which are made in the form of multiple choice tests could also be categorized as a traditional test. Various examinations test that use multiple choice questions, for example, general tests, semester exams, college entrance examination, entrance examination of employees, were also in the category of traditional tests.

The Language Centre has successfully designed a kind of test instrument which can be used to measure a person's Indonesian proficiency. The test is known as the Indonesian language proficiency test, and furthermore it is called as UKBI. UKBI is a standard test that was developed in accordance with modern testing theory and is designed to measure a person's proficiency in the Indonesian language, both spoken and written. UKBI has been tested to Indonesian speakers from diverse social strata, occupation, and educational background. In addition, UKBI also had been tested to foreign speakers (Solihah dan Dony, 2005:1).

The materials of UKBI were the use of Indonesian language which implemented in various fields, such as history, culture, law, and economics. The material was taken from various sources, among others, the mass media (electronic and print) and / or books. With that materials, the UKBI test the competence of orally and writing communication in Indonesian, both concerning the ability of receptive and productive. The receptive abilities related to understanding the content of spoken discourse and written discourse contents and the sensitivity to Indonesian language rule. The receptive abilities tested in the form of multiple choice questions with four options. Meanwhile, the productive capability relates to use the Indonesian language skills in written and oral ability. The skill in using the written Indonesian language is measured by the arrangement of written discourse. And the skill in using the oral Indonesian language is measured by the interview which consists of the monolog and dialog (Team of UKBI, 2003: 4).

Nurgiyantoro (2010:284-323) has stated that there are several language tests, they are the integrative, pragmatics, and communicative test. The language proficiency test is a type of test that is designed to measure the language proficiency of the test participants regardless where and when the participant has acquired the language skills. The content and the arrangement of this test type were not associated with the syllabus or teaching program of the specific language (Heaton in Widiastuti, 2006: $61)$.

Brown (2004:83-86) stated that there are four of English language proficiency tests which are commercialized internationally, they are TOEFL (Test of English as Foreign LAnguage, MELAB (Michigan English Language Assesment Battery), IELTS (International English Language Testing System), and TOEIC (Tes of English for International Communication). These four types of tests are intended to measure all of the language competence. Each of these types of tests has differences in implementation. This can be seen in the following table. 
Tabel 1 The differences between TOEFL, MELAB, IELTS, and TOEIC

\begin{tabular}{|c|c|c|c|c|}
\hline & TOEFL & MELAB & IELTS & TOEIC \\
\hline Producer & $\begin{array}{l}\text { The test service } \\
\text { in education } \\
\text { field }\end{array}$ & $\begin{array}{l}\text { English } \\
\text { Institute, } \\
\text { University of } \\
\text { Michigan }\end{array}$ & $\begin{array}{l}\text { Arranged jointly by } \\
\text { the Association of } \\
\text { Local exams in } \\
\text { University of } \\
\text { Cambridge (UCLES), } \\
\text { the British Council, } \\
\text { dan IDP Education } \\
\text { Australia }\end{array}$ & $\begin{array}{l}\text { International testing } \\
\text { group, educational } \\
\text { testing services }\end{array}$ \\
\hline Goal & $\begin{array}{l}\text { To test all the } \\
\text { proficiency } \\
\text { (language } \\
\text { skills) }\end{array}$ & $\begin{array}{l}\text { To test all the } \\
\text { proficiency } \\
\text { (language } \\
\text { skills) }\end{array}$ & $\begin{array}{l}\text { To test all the } \\
\text { proficiency (language } \\
\text { skills) }\end{array}$ & $\begin{array}{l}\text { To test all the } \\
\text { proficiency (language } \\
\text { skills) }\end{array}$ \\
\hline $\begin{array}{l}\text { Market } \\
\text { coverage }\end{array}$ & $\begin{array}{l}\text { Almost all } \\
\text { exclusively } \\
\text { universities and } \\
\text { colleges for } \\
\text { educational } \\
\text { purposes }\end{array}$ & $\begin{array}{l}\text { A large part of } \\
\text { the Anglo- } \\
\text { American and } \\
\text { Canada } \\
\text { language } \\
\text { program; some } \\
\text { of education } \\
\text { field in } \\
\text { worldwide }\end{array}$ & $\begin{array}{l}\text { Professional } \\
\text { organizations and } \\
\text { academic institutions } \\
\text { in Australia, Britain, } \\
\text { Canada, and New } \\
\text { Zealand. The } \\
\text { academic institution } \\
\text { in the United States } \\
\text { began accepting } \\
\text { IELTS for } \\
\text { educational purposes. }\end{array}$ & $\begin{array}{l}\text { World industrial } \\
\text { labor, trade, and } \\
\text { businesses around the } \\
\text { world. }\end{array}$ \\
\hline Type & $\begin{array}{l}\text { Computer based } \\
\text { (and the two } \\
\text { part of test are } \\
\text { the computer } \\
\text { adaptive) } \\
\text { The paper based } \\
\text { version is also } \\
\text { available }\end{array}$ & Paper based & $\begin{array}{l}\text { Computer based } \\
\text { (consists of reading } \\
\text { and writing test); } \\
\text { paper based is used } \\
\text { for the listening and } \\
\text { speaking module }\end{array}$ & $\begin{array}{l}\text { Computer based and } \\
\text { the paper based } \\
\text { version is also } \\
\text { available }\end{array}$ \\
\hline $\begin{array}{l}\text { Response } \\
\text { model }\end{array}$ & $\begin{array}{l}\text { Multiple choice } \\
\text { and essay } \\
\text { response }\end{array}$ & $\begin{array}{l}\text { Multiple choice } \\
\text { and essay } \\
\text { response }\end{array}$ & $\begin{array}{l}\text { Multiple choice, } \\
\text { essay, and oral } \\
\text { response }\end{array}$ & $\begin{array}{l}\text { Multiple choice } \\
\text { response }\end{array}$ \\
\hline $\begin{array}{l}\text { Time } \\
\text { Allocation }\end{array}$ & $\begin{array}{l}\text { Up to four } \\
\text { hours (computer } \\
\text { based); three } \\
\text { hours (paper } \\
\text { based) }\end{array}$ & 2,5 to 3,5 hours & $\begin{array}{l}\text { Two hours and forty } \\
\text { five minutes }\end{array}$ & Two hours \\
\hline
\end{tabular}

In contrast to the above explanation, Indonesia proficiency test until now only known as one type of test, i.e. UKBI. UKBI developed by the Language Center of the National Education Ministry which is now known as the Agency for Founding and Language Development. UKBI embodied in the form of batteries A, B, C, and D. Based on the problem difficulties or the difficulty level, the battery of UKBI divided into two types, namely type 1 and type 2 . Type 1 is designed for those who have more complex communication needs for vocational and / or academic purposes. Meanwhile, type 2 is designed for those who have a need for simpler communication for social and / or vocational purposes. Thus, the questions of battery type 1 have a higher difficulty level or a weight heavier scale of questions than about the battery type 2. The time required to do all the sections of UKBI is 2 hours and 15 minutes.

Based on the differences in every standardized test, both the standardized tests of English and the standardized tests of Indonesian, it is necessary to describe some theories which related to matters that determine the standardized tests. The matters of which are related to the content, presentation, and readability. 
Sakri in Nababan (2003:62) stated that the readability indicates the degree of ease of an article to be understood its point. The readability depends on the average length of sentences, the number of new words and the used of grammatical complexity stated by Richards in Nababan (2003:63). In addition, the use of foreign and regions words, taxa words and sentences, and incomplete sentences are also factors that cause the text readability becomes low. Suladi, et al. (2000:5) complements the above opinion by stating that in order to measure the level of readability need to consider several variables, namely the structure of the language, the content of the discourse, the typography, and the interest in reading.

In complementing the above opinion, the readability can be seen from several elements, among others, the ease, the attractiveness, and the understandable (Gilliland, 1972). The ease related to writing style, that is the typefaces such as the use of letters, the regularity distance, and so on. The ease associated with the word recognition speed, error rate, clarity, and speed of eye fixations in reading. The attractiveness related to interest in reading, the density of ideas in reading, and the writing style beauty. The understandable associated with the characteristics in using the words and sentences, such as the short-length of sentences and the rate / frequency of the use of words, phrases, clauses within the sentences. Furthermore, Klare (1984: 726) stated that the readability includes three things namely, the typography, the interest in reading adjusted to the values contained in the reading, and the writing style. Several theories about the readability indicators have been expressed by some experts. For example the use of Fry graphs, the Fog formula, the Flesch formula, and the Cloze test (Ginting, 1997: 56). To measure the readability of the Indonesian text is more commonly used.

Alibakhshi and Ali (2011:1304) in their study of TOEFL external validity of the doctoral entrance examination in Iran stated that the external validity (in general) is one aspect of construct validity associated with the inference which considered as the basic of the test participants assessment. The external validity is considered as the essential in a high level test, such as the English test for the academic/special purpose which is used to evaluate the test participant proficiency in English generally in order to investigate the TOEFL test validity in general that is being used by the universities in Iran to determine the Ph.D. candidates. Therefore, it is used the mix design research. The quantitative data were collected through a self-assessment instrument that contains personal information and 40 items of questions which is designed on five points in Likert scale. A total of 450 students from various universities of doctoral program in Iran had participated in this study. The research data were analyzed using descriptive and inferential statistics which include the approach of principal component analysis, the same analysis of variance and regression analysis. The Qualitative data were analyzed through content analysis. The Result of the study indicates that there is a significant difference between the average value of the participants in the TOEFL test with a mean value of them in academic language skills. Furthermore, TOEFL scores could not predict the participants test scores significantly in the use of academic language at the situation using the target language. Therefore, the TOEFL test developers should take the proficiency issue in general for the consideration when planning the TOEFL test.

The research result of Alibakhshi and Ali (2011) can be used as a basis in the development of Indonesian language competence test model by taking into account the academic background of the test participants. The suitability between the test materials and the academic background of the test participants can predict the academic ability based on the subject disciplines studied. As a diagnostic tool, the instrument developed should be able to predict the results that will be achieved based on the results of the test conducted.

Behfrouz and Nahvi (2013:30) in their study entitled "The Effects of Test Instrument on Reading Ability in IELTS" explained that one of the abilities that involves thinking was reading. Reading is a capability that makes the students become familiar with the ideas of others; compare and contrast the different ideas; testing and evaluating arguments, interpretations, beliefs, or theories; make inferences, predictions, or interpretation; and explore the implications and consequences. In essence, reading is an ability that encourages students to think critically. Therefore, this study aimed to investigate the influence of the characteristics of test instrument on the ability of the students on the reading in the IELTS test. To complete the research purposes, a sample of 50 boys and girls had participated in this study. To ensure the homogeneity of the test participants and to determine the level of student proficiency in reading, a reading section of IELTS test has been carried out at the beginning of the study. Furthermore, the five forms of IELTS test is given to the participants. The Data were analyzed using oneway ANOVA and Scheffe test. Data revealed that the participants showed a difference in the IELTS test 
because of differences in the form of test instrument given as an action. The results showed that the characteristics of the test instrument have a significant influence on the ability to reading test on the IELTS test.

Based on the research results by Behfrouz and Nahvi (2013) above, the development of Indonesian language competence test model also need to consider the characteristics of the test instrument. The characteristics differences of the test instrument which significantly could distinguish the ability of the test participants need to be conducted in order to be able to demonstrate the validity of the test instrument.

Namdar and Bagheri (2012: 150) in their research on the effect of instructing the behavior of impression management in maximizing the performance of applicants in the IELTS speaking test exposed that the speaking activity deemed to be within the constraints of time. When the speaking process conducted, the speaker is in a position under constant pressure to follow the messages received and led to the rapid formulation to respond his/her partner. In the IELTS speaking test, the understanding of communicative interview creates an ideal situation for potential employees / job applicants to use the impression management behavior. Sixty IELTS students who study at the Institute of Baahar in Shiraz, Iran was selected for this study and were divided into two groups: control and experimental. The experimental group received the treatment and the students are taught tactics of impression management. At the end of the program, students participate in the test and their verbal abilities assessed by a certified IELTS examiner. Interview processes were also recorded by video and the participants were asked to follow the posttest interview and asked to complete a questionnaire of posttest. The result of research proves the positive influence of impression management instruction in the performances of the candidates on IELTS speaking test.

Veerappan and Sulaiman (2012: 138) in a study entitled "A review of the IELTS Writing Test, Results of The test, and Reliability between the assessors show that assessment could not be trusted and there was a difference of opinion between the assessors who provide different assessment. The total accumulated score as much as 588 of the maximum score 900 and the rate score of nine students as much as $65.3 \%$ and failed to reach the limit values were six students. Test of IELTS uses a holistic assessment, the assessor reveals that the assessment rubrics are unclear in defining the quality of writing. This assessment revealed analytical scoring system as a better procedure in assessing the IELTS test, in which the system uses separate scales for assessing the aspects of different writing than with a single score. The reliability between the assessors can be overcome if the test providers can complement the assessment scale that can be clearly equate the total value obtained by a person which could not be generalized to all of the IELTS candidates. Furthermore, there are many limitations in this study such as the lack of learning preparation by the students, the experience of the assessors to assess, limited time, reliability of the test and the methods validity of the score tabulation.

UKBI as a test instrument for measuring language competence need to be analyzed its content, presentation and readability based on the theories above. Therefore, it can be seen from the usage values of the test result conducted by applying the instrument of UKBI. The reliability of UKBI instrument will have an impact on its meaning to a policy making.

\section{METHODS}

Generally, the research method is belonging to the research and development (R\&D) domain. It is conducted as the preliminary study in order to determine the background field of the problem statements in the case of Indonesian language competence test. In particular, the method used in this research is descriptive qualitative research methods. Objects that were examined in this study is a Indonesian language proficiency test instruments, which consists of five parts, namely listening, responding rules, reading, speaking, and writing. The analysis technique used is content analysis with the data validity test using the triangulation theory. 


\section{RESULT AND DISCUSSION}

UKBI instrument in general can be described in the following table.

Table 2 The skill tested, the number of test instrument, and the time allocation of UKBI instrument.

\begin{tabular}{|l|l|l|l|}
\hline \multicolumn{1}{|c|}{ The Skill Tested } & $\begin{array}{c}\text { The Number of } \\
\text { Test Instrument }\end{array}$ & $\begin{array}{c}\text { Time } \\
\text { Allocation }\end{array}$ & $\begin{array}{c}\text { Test Instrument } \\
\text { Form }\end{array}$ \\
\hline Listening & 40 & 25 minutes & Multiple Choice \\
\hline Responding the Rule & 25 & 20 minutes & Multiple Choice \\
\hline Reading & 40 & 45 minutes & Multiple Choice \\
\hline Writing & 1 & 30 minutes & Practice \\
\hline Speaking & 1 & 15 minutes & Practice \\
\hline
\end{tabular}

Based on the table above, UKBI instrument analysis is based on three principal study, namely: (1) the content, the content analysis in UKBI based on two aspects, namely communication skills that are tested and the material; (2) the presentation, the presentation is analyzed based on aspects of the matter and the time required to perform each competency; and (3) the readability, the readability is analyzed based on typography, interest in reading, and writing style.

\section{The Content}

\section{a. The Communication Skills Tested}

The Communication skills tested were listening skills, responding rules, reading, speaking, and writing. The skills of responding rule need to be consider again because based on the pragmatics and communicative assessment theories, the assessment that related to grammar mastery can be conducted in the same time with the implementation of the four language skills assessment. Thus, the assessment of competence in Indonesian language fairly categorized into two, namely expressive (speaking and writing) and receptive (listening and reading).

The skill of reponding the rule in Indonesian Language Competence Test (UKBI) is carried out separately in the discontinuous context. It can be seen in the following example.

The immigrants occupied the residence

\section{(A) Settlement}

(B) Settlement area

that has been provided by the government

(C) was provided

(D) has been provided

Para transmigran menempati pemukiman yang
(A) permukiman
(B) daerah permukiman

telah disediakan oleh pemerintah daerah setempat.

(C) sudah disediakan

(D) telah disediakan

The question above is considered as very important in formal writing in the term of correct language use of Indonesian. However, the facts in everyday communication people are more familiar to the word residence (pemukiman) rather than settlement (permukiman) as a meaningful word to settle an area. It coused some misunderstanding in speech. Therefore, grammar response questions will be more meaningfull if they have been integrated with some questions that were used for measuring the receptive ability or students' productivity.

The integration of question response in receptive abilities or productivity can be presented in the form of reading competence test as follows. 


\section{Directions:}

Complete the following hiatus sentences! The answer shall not be more than one word.

A house that has a good (1) ... and decent enough to be called home (2) ... Besides a good ventilations, (3) ... morning sunshine also supports our health system for the occupants. The design is also very important to be considered, whether it is interior design or (4) ... One of which is open green space on the roof since (5) ... able to reduce the heat.

Rumah yang memiliki (1) ... yang baik dan cukup biasa disebut dengan rumah (2)... Selain sirkulasi udara yang baik, (3)... matahari pagi bisa membuka sistem kesehatan tersendiri bagi penghuninya. Desain rumah juga perlu diperhatikan, baik desain interior maupun (4)... . Salah satunya adalah ruang hijau di bagian atas rumah karena (5)... dapat meredam panas.

The questions above, besides can be used to measure the students' reading ability, also can be used to measure language competence, especially in terms of grammar and vocabulary.

\section{b. Materials}

The materials which are developed as the instrument of UKBI taken from various fields (e.g. law, social, economic, etc.). The material was taken from the mass media (print / electronic) and books. It has the weakness if the test instruments were done by participants who have the background knowledge suitable with the test instrument. It means that the acquirement of high scores could be achieved not due to understand about the test instrument, but it due to the background knowledge before. Therefore, the materials of the test instrument should be neutral through the process of materials selecting which needed in general. The passages contents which do not in accordance with the interests and needs, experience and cognitive range, and do not in accordance with the subject being studied, it will add to the difficulty level of discourse. In addition to these aspects, test instruments should be free from political and religious elements in order to avoid the conflicts.

The preference of natural science field can be seen in the passage about the coelacanth fish. In the such passage, it can be found many of vocabularies which have known by the students which came from the natural science class. Other vocabularies are Latimeria Chalemnae, taxonomy, Latimeria manadoensis, the comoro, and the zoology.

The passage is considered as easier to be better understood by the students who came from the natural science background than the students who came from the social science background. It happens because the vocabularies are easier to be understood by the students who came from the same background knowledge with the terms.

\section{The Presentation}

\section{a. The Test Instrument Form}

The test instrument of UKBI is presented in the form of multiple choice questions for the listening, responding the rule, and reading, whereas speaking and writing are presented in the form of images. The form of such test instrument has advantages and weaknesses. The advantages of the multiple choice form are the time correcting is faster than the subjective tests form, in addition, the coverage of material presented can be complex. However, the form of such test instrument also contains some weaknesses, they are:

1) The form of multiple choice questions provide great opportunities to the participants to work together;

2) The form of multiple choice questions may not be able to photograph the actual competence because there is a great chance to answer with a guess based on the multiple choice answers which has already available;

3) The form of responding rule of test instrument can be a kind of trap to test participants who do not really understand the instructions of the test instrument; 
4) The form of the speaking and writing test instrument that is presented in the form of a picture can be a problem if the prints of the pictures in the test instrument's paper are not good in quality;

To overcome these weaknesses, it is suggested to apply some of the following:

1) The form of the test instrument remains in the form of an objective type, but it should be combined between the filling gaps test questions type, true-false, matching, multiple choice, paraphrasing type, etc.

2) The form of speaking test instrument should not be an image that required a description, but it should be in the form of an issue written on a card (Q-card), then the test participants give comments based on the topic stated in the card.

3) The form of writing skill test instrument should not only consist of one task, but two tasks. The first task is describing the data or an image and the second task is giving an opinion related to the topic given by considering the number of the words written.

b. The time allotment to finish each section of the test instrument

The number of time allotment to finish all the test instrument sections of UKBI is 135 minutes which consist of:

1) Listening: 25 minutes to finish 40 items of test instrument questions

2) Responding the rule: 20 minutes to finish 25 items of test instrument questions

3) Reading: 45 minutes to finish 40 items of test instrument questions

4) Writing: 30 minutes to finish

5) Speaking: 15 minutes to finish

Based on the description of the time division on each skill tested, it presents the irregularities on listening, responding the rule, and reading skills.

1) Listening skill: the test instrument question which consists of 40 items that should be finished in 25 minutes requires the test participant to be able to finish each question in less than one minute. The test participants were impressed as they were not given the opportunity to think about the answer to be chosen.

2) Responding the rule: the task in responding the rule which consists of 25 numbers of items should be done in limited time as 20 minutes, so that there is an unfair indication to finish the task items. It suggested having one minute for each number of the task items.

3) Reading skill: In reading the passage, the test participant should have an extra time to finish the passage that consider as the basic to answer the questions given. There are five passages presented in the reading test instrument and consists of eight item questions for each passage so that only one minute for a passage to be understood by the test participant.

\section{The Readability of the Text}

\section{a. Typograph}

The Typograph relates to the structure and use of the letter. UKBI test instrument has already fulfill the standards if is examined from typograph elements. It is known by the selection of letter, spacing, and the layout which consider as suitable with the standards requirement. There are only on some test sections that need a little bit improvement. For example in section II (responding rules), space adjusting and layout setting should refer to the principle of consistency that the reader is easier to understand the text that has been read. Associated with the use of letters, it is considered as appropriate because of the element of readability has already qualified.

\section{b. The Reading Interest}

Relating to the opinion of Klare (1984: 726), interest in reading affects the readability of a text. It is related to the density of ideas, clarity of ideas, and the beauty. Referring to the UKBI test instrument, elements of interest in reading is regarded as a necessity. That is, participants are required to read and understand the idea. In section III (reading), some text has been implementing this element. For 
example there is a task item type in the form of procedure text, exposition text, and explanation text. When UKBI is compared with other language proficiency test, for example TOEFL and IELTS, then there is equivalence in the text variations presented. It will affect interest in reading the text readability. However, based on interviews with some respondents who had ever take part in UKBI test, they stated that their reading interest toward the text presented as a basis for answering the questions were in the low condition. It was happened because the texts presented were lack in attracting their reading interest. The texts presented were too general and considered as less useful, for example, the dialog presented in the listening test which related to a person being in the salon and a passage about the product of formula milk. To attract the interest in reading of the test participants, the test instrument arrangers should be considering the urgency of the information presented.

\section{c. The Writing Style}

The Writing Style is associated with the characteristic of the diction used, the selection of topics, and conformity with the reader. Selection of reading material of UKBI test in section III covers several fields of study. It can be said to correspond to the main purpose of holding the Indonesian language proficiency test. Some inputs that can be raised related to legibility elements are as follows.

1) Selection of reading material should be more common / general.

2) The use of diction should not refer to specific disciplines.

3) Selection of the theme / topic can shows the wisdom of Indonesian culture.

4) Preparation of questions based on the level of difficulty.

5) Preparation of questions based on some elements of legibility.

6) Question sorted by voice response that was played (in the listening test) so difficult problem does not caused by a sequence of questions that intentionally scrambled.

\section{THE CONCLUSION}

Based on the analysis of UKBI test instruments, based on its content, presentation, and legibility, it is known that the test instrument of UKBI still contains some weaknesses. Relating to the content aspect, it was analyzed based on the tested skills and its materials. Skills in responding the rule in UKBI test instrument were less relevant to the theory of pragmatics and communicative assessment. The material tested allow for differences in the ability of the test participants based on the test participants background. The form of multiple choice questions in UKBI test instrument was considered as a weakness of this test instrument.

\section{REFERENCES}

Alibakhshi, Goudarz dan Ali, Hassan Ghand. (2011). External validity of TOEFL section of Doctoral Entrance Examination in Iran: a mixed design study. Theory and Practice in Language Studi 1 (10) 1304-1310.

Behfrouz, Behnam \& Nahvi, Elham. (2013). The effect of task characteristics on IELTS reading performance. Open Journal of Modern Linguistics 3 (1) 30-39.

Brown, H. Douglas. (2004). Language assesment, principles and classroom practice. San Fransisco: Longman.

Gilliland, John. (1972). Readability. London: Holder and Stoughton.

Ginting, Setia. (1997). Mencari formula keterbacaan bahasa Indonesia untuk kepentingan pengajaran. Jurnal Widya 146 (14) 56-62.

Klare, G.R. (1984). Readability: Handbook of reading research. New York: Longman Inc.

Nababan, M. Rudolf. (2003). Teori Menerjemah Bahasa Inggris. Yogyakarta: Pustaka Pelajar.

Namdar, Sara \& Bagheri, Mohammad Sadegh. (2012). The effect of instructing impression management behaviour on maximizing applicants' performance in the IELTS speaking test. English Language Teaching, 5 (4) 150-160.

Nurgiyantoro, Burhan. (2010). Penilaian pembelajaran bahasa berbasis kompetensi. Yogyakarta: BPFE.

Solihah, Atikah \& Dony Setiawan. (2005). Bedah Soal UKBI. Jakarta: Pusat Bahasa, Departemen Peniikan Nasional. Suladi; Astuti, Wiwiek Dwi, \& Biskoyo, K. (2000). Keterbacaan kalimat bahasa Indonesia dalam Buku Pelajaran SLTP. Jakarta: Departemen Pendidikan Nasional.

Tim UKBI. (2003). Uji kemahiran berbahasa Indonesia. Jakarta: Pusat Bahasa, Depdiknas. 
The Content Analysis, The Presentation, And The Instrument Readability Of Indonesian...

Veerappan, Veeramuthu dan Sulaiman, Tajularipin. (2012). A review on IELTS test, its test results and inter rater reliability. Theory and Practice in Language Studies, 2 (1) 138-143.

Widiastuti, Udiati. (2006). Uji kemahiran berbahasa Indonesia sebagai sarana evaluasi dalam perencanaan bahasa di Indonesia. Linguistik Indonesia 24 (1). 